\title{
An SSU rDNA barcoding approach to the diversity of marine interstitial cercozoans, including descriptions of four novel genera and nine novel species
}

\author{
Chitchai Chantangsit and Brian S. Leander
}

Correspondence

Chitchai Chantangsi

chitchai.c@chula.ac.th or

chantangsi01@hotmail.com

\author{
Departments of Zoology and Botany, University of British Columbia, Biological Sciences Bldg, 6270 \\ University Blvd, Vancouver, BC V6T 1Z4, Canada
}

\section{INTRODUCTION}

Marine benthic environments are complex and poorly understood ecosystems that contain a diverse array of micro-organisms (Fenchel, 1987; Hondeveld et al., 1992). Environmental DNA surveys of these systems have demonstrated a significant degree of hidden diversity, especially of so-called cercozoan amoeboflagellates (Bass \& CavalierSmith, 2004; Berney et al., 2004; Šlapeta et al., 2005). The group Cercozoa was initially recognized as a monophyletic

tPresent address: Department of Biology, Faculty of Science, Chulalongkorn University, Phayathai Road, Pathumwan, Bangkok, 10330 Thailand.

Abbreviations: $\operatorname{cox} 1$, cytochrome $c$ oxidase subunit 1; K2P, Kimura twoparameter; SSU rDNA, small subunit rDNA; LM, light microscopy; ML, maximum-likelihood.

The GenBank/EMBL/DDBJ accession numbers for the SSU rDNA sequences of the marine benthic interstitial cercozoans examined in this study are FJ824121-FJ824131.

A supplementary table giving details of the SSU rDNA nucleotide sequences included in the analyses performed for this study is available with the online version of this paper. assemblage based on molecular phylogenetic studies inferred from rDNA genes (Cavalier-Smith, 1998a, b). Subsequent studies have shown that several protists incertae sedis are also members of this group (e.g. organisms of the genus Ebria) and that there are many novel environmental sequence clades that have yet to be described at the microscopic level (Bass \& Cavalier-Smith, 2004; Hoppenrath \& Leander, 2006a, b). Cryomonads (e.g. members of the genus Protaspis) are a group of cercozoan biflagellates that glide along substrates with heterodynamic flagella and are common predators in marine benthic habitats (Hoppenrath \& Leander, 2006a). These particular cercozoans possess several morphological characteristics (e.g. flattened cell shape, mode of locomotion and a conspicuous nucleus with condensed chromatin) that resemble distantly related eukaryotes living in the same environments, namely some phagotrophic euglenids, dinoflagellates and katablepharids. These convergent morphological and behavioural features have led to difficulties in the classification and identification of benthic biflagellates in general, but especially in cercozoan lineages, which are very poorly understood. 
DNA barcoding has been proposed as an alternative and more precise approach for the delimitation and identification of species. This strategy is expected to be particularly advantageous for understanding the diversity of uncultured microeukaryotic lineages that lack sufficient morphological details for species delimitation (Godfray, 2002; Hebert et al., 2003a, b; Tautz et al., 2002, 2003). Hebert et al. (2003b) proposed the mitochondrial cytochrome $c$ oxidase subunit 1 (cox 1$)$ gene as a pragmatic and widely applicable 'DNA barcode' for animal species. Although this gene has proved useful for the identification of animal species and even some protists (Barth et al., 2006; Chantangsi et al., 2007; Lynn \& Strüder-Kypke, 2006; Saunders, 2005), the gene is not applicable for all groups of eukaryotes due to several limitations (Scicluna et al., 2006). For example, some groups of eukaryotes are amitochondriate and therefore lack the coxl gene, and most other groups of eukaryotes have yet to be studied at the level of the mitochondrial genome. Moreover, a few groups of eukaryotes, such as ciliates, have different-sized insertions within the coxl gene that create difficulties in the PCR amplification of the barcode sequences (Cummings, 1992; Norman \& Gray, 1997). In addition, the mitochondrial genome of a freeliving diplonemid Diplonema papillatum has been found to show fragmented coding regions for the coxl gene (Marande \& Burger, 2007).

Nuclear small subunit rDNA (SSU rDNA) sequences are the molecular markers that are most widely used to study the phylogenetic relationships of eukaryotes and prokaryotes. The SSU rRNA gene is present in all organisms and plays a highly conserved role in protein translation that is critical for the survival of cells; therefore, this sequence can be compared across the entire tree of life. This gene is also present in numerous copies within the genome and contains highly conserved regions that facilitate the design of universal primers for PCR amplification (Long \& David, 1980; Minelli, 1993; Sogin et al., 1986). SSU rDNA sequences also contain regions of sequence variation that are sufficient and advantageous for DNA barcoding; for instance, Scicluna et al. (2006) demonstrated the utility of a 600 bp segment of SSU rDNA sequences for identifying subtypes of the Blastocystis hominis species complex.

In order to better understand the microeukaryotic components of marine benthic ecosystems, we investigated the phenotypic and genetic diversity of uncultured marine interstitial cercozoans that showed morphological and behavioural similarities to previously described species of the genera Protaspis and Cryothecomonas (Hoppenrath \& Leander, 2006a). In particular, we examined the potential for coupling high resolution light microscopy (LM) with SSU rDNA barcodes (e.g. a 5'-618 bp fragment) for facilitating the systematics of these uncultured lineages. We also used light micrographs and SSU rRNA gene sequences to help establish the cellular identities of several environmental DNA sequence clades. Overall, this combined approach enabled us to (i) describe nine novel species within four novel genera and one described genus of uncultured marine interstitial cercozoans and (ii) establish an efficient and effective protocol for advancing the systematics of this group.

\section{METHODS}

Sampling and LM. Sand samples were collected from several habitats around British Columbia, Canada, during 2006-2007. Organisms were extracted from the sand samples through a $48 \mu \mathrm{m}$ mesh using a melted seawater-ice method as described by Uhlig (1964). Briefly, 2-3 spoons of sand samples were placed into an extraction column wrapped with the mesh. Two to three seawater ice cubes were then put on top of the sand samples and left to melt over several hours. The organisms of interest were separated through the mesh and concentrated in a Petri dish that was filled with seawater and placed underneath the extraction column. The Petri dish containing the organisms was then observed using a Leica DMIL inverted microscope. Cells were isolated individually and placed on a slide for LM using phase-contrast and differential interference contrast (DIC) microscopy with a Zeiss Axioplan 2 imaging microscope connected to a Leica DC500 colour digital camera.

DNA extraction and PCR amplification. Cells were isolated individually and washed three times in autoclaved filtered seawater. The numbers of cells from which different SSU rDNA sequences were obtained were as follows: Protaspis obliqua (isolate 1) one cell; $P$. obliqua (isolate 2) 10 cells; the number of isolated cells was not recorded for Protaspis rotunda sp. nov.; Protaspis obaniformis sp. nov. four cells; Protaspis oviformis sp. nov. 25 cells; Botuliforma benthica gen. et sp. nov. 14 cells; Ventrifissura artocarpoidea gen. et sp. nov. one cell; Ventrifissura foliiformis gen. et sp. nov. 12 cells; Verrucomonas bifida gen. et sp. nov. 15 cells; Verrucomonas longifila gen. et sp. nov. one cell; and Discomonas retusa gen. et sp. nov. one cell. DNA was extracted using the protocol provided in the Total Nucleic Acid Purification kit by EPICENTRE. PCR with the final reaction volume of $25 \mu \mathrm{l}$ was performed for two rounds in a thermal cycler using puReTaq Ready-To-Go PCR beads (GE Healthcare Bio-Sciences, Inc.). The first round PCR was conducted using forward (i.e. NPF1 or PF1) and reverse primers (i.e. R4 or FAD) as listed in Table 1. Then, either direct PCR or a gel-purified band of an 1850 bp region from the first round PCR was used as a template for the second round PCR with the appropriate primers provided in Table 1. The thermal cycler was programmed as follows: hold at $94{ }^{\circ} \mathrm{C}$ for $4 \mathrm{~min}$; five cycles of denaturation at $94{ }^{\circ} \mathrm{C}$ for $30 \mathrm{~s}$, annealing at $45^{\circ} \mathrm{C}$ for $1 \mathrm{~min}$, and extension at $72{ }^{\circ} \mathrm{C}$ for $105 \mathrm{~s} ; 35$ cycles of denaturation at $94{ }^{\circ} \mathrm{C}$ for $30 \mathrm{~s}$, annealing at $55{ }^{\circ} \mathrm{C}$ for $1 \mathrm{~min}$, and extension at $72{ }^{\circ} \mathrm{C}$ for $105 \mathrm{~s}$; and hold at $72{ }^{\circ} \mathrm{C}$ for $10 \mathrm{~min}$. PCR products corresponding to the expected size were separated by agarose gel electrophoresis and cleaned using the UltraClean 15 DNA Purification kit (MO BIO Laboratories, Inc.). The cleaned DNA was cloned into a pCR2.1 vector using TOPO TA Cloning kits (Invitrogen Corporation). Plasmids with the correct insert size were sequenced using BigDye 3.1 and the vector forward and reverse primers, and internal primers with an Applied Biosystems 3730S 48-capillary sequencer (Table 1).

Sequence alignment. Sequences were assembled and edited using Sequencher (version 4.5, Gene Codes Corporation). Acquired sequences were initially identified by BLAST analysis. New SSU rDNA sequences derived from the newly found cercozoans were aligned using CLUSTAL W (Thompson et al., 1994) implemented in the MEGA version 4 program (Tamura et al., 2007) and further refined by eye. Four multiple sequence alignments were created for phylogenetic analyses: (i) a 69-taxon global alignment comprising sequences of representatives from all major eukaryotic groups (1134 unambiguous sites) was constructed to determine the phylogenetic affinities of the 
Table 1. Oligonucleotide primers used for amplification and sequencing of SSU rDNA in this study

Annealing region was provided with reference to the SSU rDNA sequence of Protaspis rotunda sp. nov. (GenBank accession no. FJ824123).

\begin{tabular}{|c|c|c|c|}
\hline Primer & Direction & Sequence $5^{\prime}-3^{\prime}$ & Annealing region \\
\hline $\mathrm{NPF} 1^{*}$ & Forward & 5'-TGCGCTACCTGGTTGATCC-3' & $1-19$ \\
\hline PF1 & Forward & 5'-GCGCTACCTGGTTGATCCTGCC-3' & $2-23$ \\
\hline $525 \mathrm{~F}$ & Forward & 5'-AAGTCTGGTGCCAGCAGCC-3' & $567-585$ \\
\hline $917 \mathrm{FD}^{*}$ & Forward & 5'-GCCAGAGGTGAAATTCTNGG-3' & $917-936$ \\
\hline $1050 \mathrm{~F}$ & Forward & 5'-GGGGGAGTATGGTCGCAAG-3' & $1130-1148$ \\
\hline $1050 \mathrm{FD}^{*}$ & Forward & 5'-GGGGGAGTATGGTCGCRAG-3' & $1130-1148$ \\
\hline $1050 \mathrm{MRD}^{*}$ & Reverse & 5'-GCCTYGCGACCATACTCC-3' & $1150-1133$ \\
\hline $1134 \mathrm{FD}^{*}$ & Forward & 5'-CGCAAGGCTGAAACHTRAAGG-3' & $1143-1163$ \\
\hline nomet1134R & Reverse & 5'-TTTAAGTTTCAGCCTTGCG-3' & $1161-1143$ \\
\hline $1242 \mathrm{RD}^{*}$ & Reverse & 5'-GTCYGGACCTGGTAAGTTTTC-3' & $1242-1222$ \\
\hline $1250 \mathrm{R}$ & Reverse & 5'-TAACGGAATTAACCAGACA-3' & $1342-1324$ \\
\hline $1367 \mathrm{RD}^{\star}$ & Reverse & 5'-TTTAGYAGGBCGAGGTCTCG-3' & $1367-1348$ \\
\hline $\mathrm{R} 4$ & Reverse & 5'-GATCCTTCTGCAGGTTCACCTAC-3' & $1823-1801$ \\
\hline FAD & Reverse & 5'-TGATCCTTCTGCAGGTTCACCTAC-3' & $1824-1801$ \\
\hline
\end{tabular}

*Primers newly designed in this study.

newly isolated organisms to other eukaryotic groups; (ii) a 67-taxon cercozoan alignment consisting of cercozoan representatives and extensive short environmental sequences about $1069 \mathrm{bp}$ in length (923 unambiguous sites) was constructed to determine phylogenetic affinities of the newly isolated organisms to uncharacterized taxa represented by sequences derived from environmental studies; (iii) a 35-taxon cercozoan alignment covering representatives from different cercozoan subgroups and excluding the shorter and unrelated environmental sequences (1617 unambiguous sites) was constructed to determine more robustly the phylogenetic relationships among the newly described taxa; and (iv) a 35-taxon cercozoan alignment including only the barcoding regions of $618 \mathrm{bp}$ in length (583 unambiguous sites) was constructed to compare the topologies of phylogenetic relationships inferred from the 1617 bp alignment 3 . Alignments 3 and 4 contained the same composition of examined taxa. All ambiguous sites were excluded from the alignments prior to phylogenetic analyses.

As for barcoding analyses, two alignment files were created for genetic distance calculations: (i) a 17-taxon cercozoan alignment of the almost complete SSU rDNA gene including 1798 bp (1745 unambiguous sites) and (ii) a 17-taxon cercozoan alignment including only the $5^{\prime}$-half 618 bp barcoding regions (608 unambiguous sites). Both datasets had the same composition of examined taxa. The second barcoding alignment file was constructed based on diagnostic barcoding regions of Blastocystis hominis (Scicluna et al., 2006): its starting position was $22 \mathrm{bp}$ inside the beginning of the $B$. hominis barcoding region and extended $65 \mathrm{bp}$ further from the end of the B. hominis barcoding region. The alignment files are available upon request.

Phylogenetic analyses. MrBayes version 3.1.2 was used to perform Bayesian analyses on all four datasets (Huelsenbeck \& Ronquist, 2001; Ronquist \& Huelsenbeck, 2003). Four Markov Chain Monte Carlo (MCMC) chains, one cold chain and three heated chains, were run for 2000000 generations, sampling every 50th generation (tree). The first 4000 trees were discarded as burn-in. The remaining trees were used to compute the $50 \%$ majority-rule consensus tree. Branch lengths of the trees were saved.

Maximum-likelihood (ML) analyses were performed on all four datasets using PhyML (Guindon \& Gascuel, 2003). Input trees for each dataset were generated by BIONJ with optimization of topology, branch lengths and rate parameters selected. The General Time Reversible (GTR) model of nucleotide substitution was chosen. The proportion of invariable sites and the gamma distribution parameter were estimated from the input dataset. Eight categories of substitution rates were selected. PhyML bootstrap trees with 100 bootstrap datasets were constructed using the same parameters as the individual ML trees.

Genetic distance analyses. Sequence divergences were calculated for $1798 \mathrm{bp}$ and $618 \mathrm{bp}$ datasets using the Kimura two-parameter (K2P) distance model with complete deletion of positions with gaps included (Kimura, 1980).

Sequence availability. The SSU rDNA nucleotide sequences included in the analyses performed for this paper are detailed in Supplementary Table S1 (see IJSEM Online). The GenBank accession numbers for the 11 new sequences obtained from this study are: Protaspis obliqua isolate 1 (1826 bp; FJ824121), Protaspis obliqua isolate 2 (1826 bp; FJ824122), Protaspis rotunda sp. nov. (1824 bp; FJ824123), Protaspis obaniformis sp. nov. (1823 bp; FJ824124), Protaspis oviformis sp. nov. (1823 bp; FJ824125), Botuliforma benthica gen. et sp. nov. (1827 bp; FJ824126), Ventrifissura artocarpoidea gen. et sp. nov. (1824 bp; FJ824127), Ventrifissura foliiformis gen. et sp. nov. (1822 bp; FJ824128), Verrucomonas bifida gen. et sp. nov. (1827 bp; FJ824129), Verrucomonas longifila gen. et sp. nov. (1828 bp; FJ824130) and Discomonas retusa gen. et sp. nov. (1824 bp; FJ824131).

\section{RESULTS}

\section{Identification of the examined flagellates}

Eleven different isolates of uncultured cercozoan flagellates were isolated and characterized by LM (Figs 1-3) and SSU rDNA gene sequences (Table 2; Figs 4-5). All organisms were found gliding in marine interstitial habitats, except for Botuliforma benthica gen. et sp. nov., which showed a 

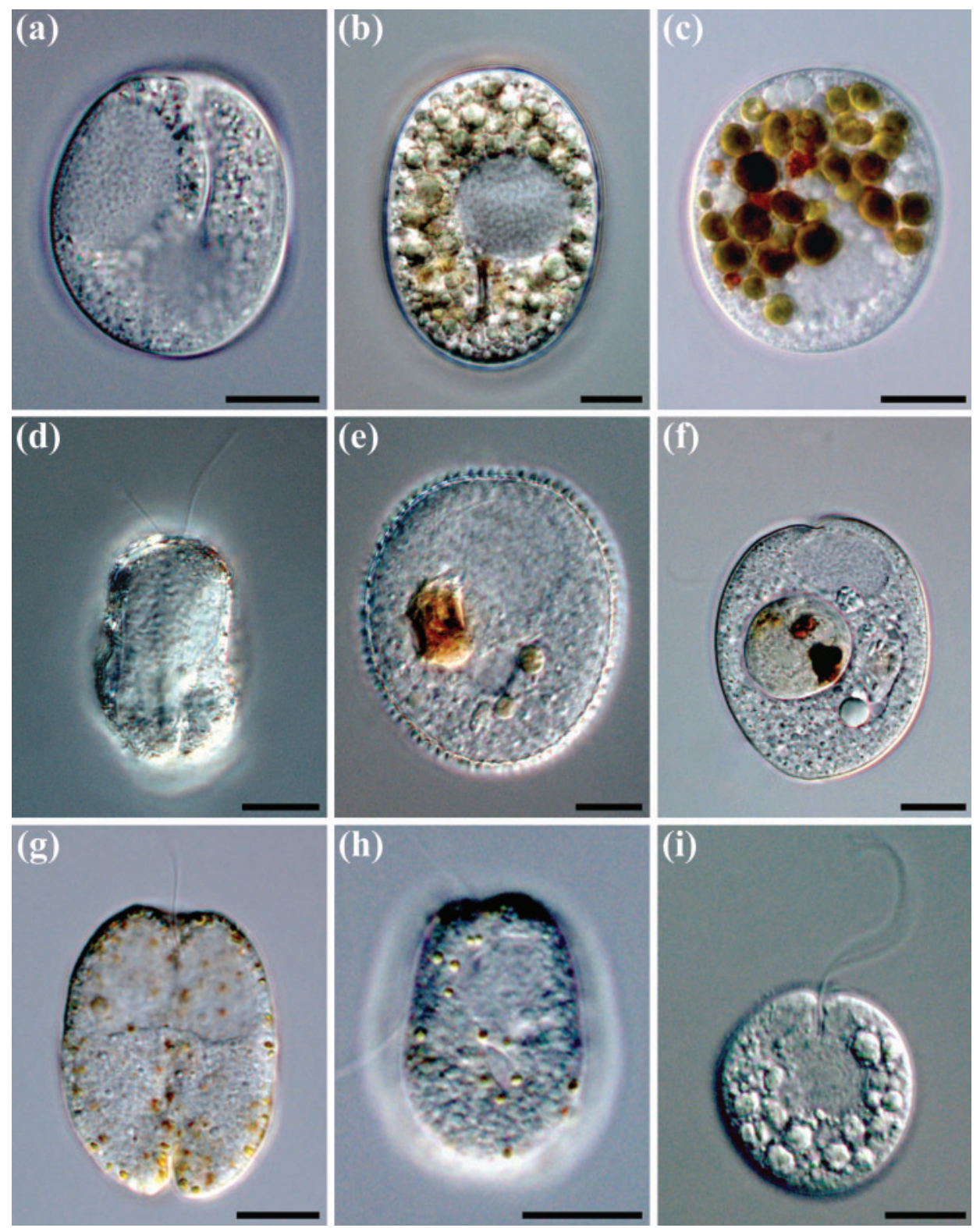

Fig. 1. Light micrographs of nine novel cercozoans found in this study. (a) Protaspis rotunda sp. nov. showing a ventral view with an ovoid nucleus at the anterior right side of the cell and a curved slit in the middle of the cell. (b) Protaspis obaniformis sp. nov. showing granulated cytoplasm, spherical nucleus in the middle of the cell and a posterior ventral slit. (c) Protaspis oviformis sp. nov. showing food particles with varying colours within its cytoplasm. (d) Botuliforma benthica gen. et sp. nov. showing two anterior flagella, a large anterior nucleus and a thick and rough cell wall. (e) Ventrifissura artocarpoidea gen. et sp. nov. showing a cell with numerous pointed warts and an anterior spherical nucleus. (f) Ventrifissura foliiformis gen. et sp. nov. showing a cell with a smooth cell surface, large food particle and a small anterior nucleus. (g) Verrucomonas bifida gen. et sp. nov. showing numerous warts of varying colours on the cell surface, a ventral furrow, a bilobed nucleus and a notch at its posterior end. (h) Verrucomonas longifila gen. et sp. nov. showing two flagella, an ovoid nucleus at the anterior of the cell and several yellowish warts on cell surface. (i) Discomonas retusa gen. et sp. nov. showing a prominent long anterior flagellum, a discoidal nucleus at the anterior of the cell and numerous spherical granules distributed around the periphery of the cell. Bars, $10 \mu \mathrm{m}$.

rotational pattern of swimming. The DNA sequence data demonstrated that the newly discovered cercozoan flagellates clustered with a diverse assortment of environmental DNA sequences, forming one previously established clade and four novel clades, as described below (Figs 4-5). These molecular data served as our primary taxonomic guides and enabled us to establish nine novel species that are challenging to distinguish at the morphological level. 

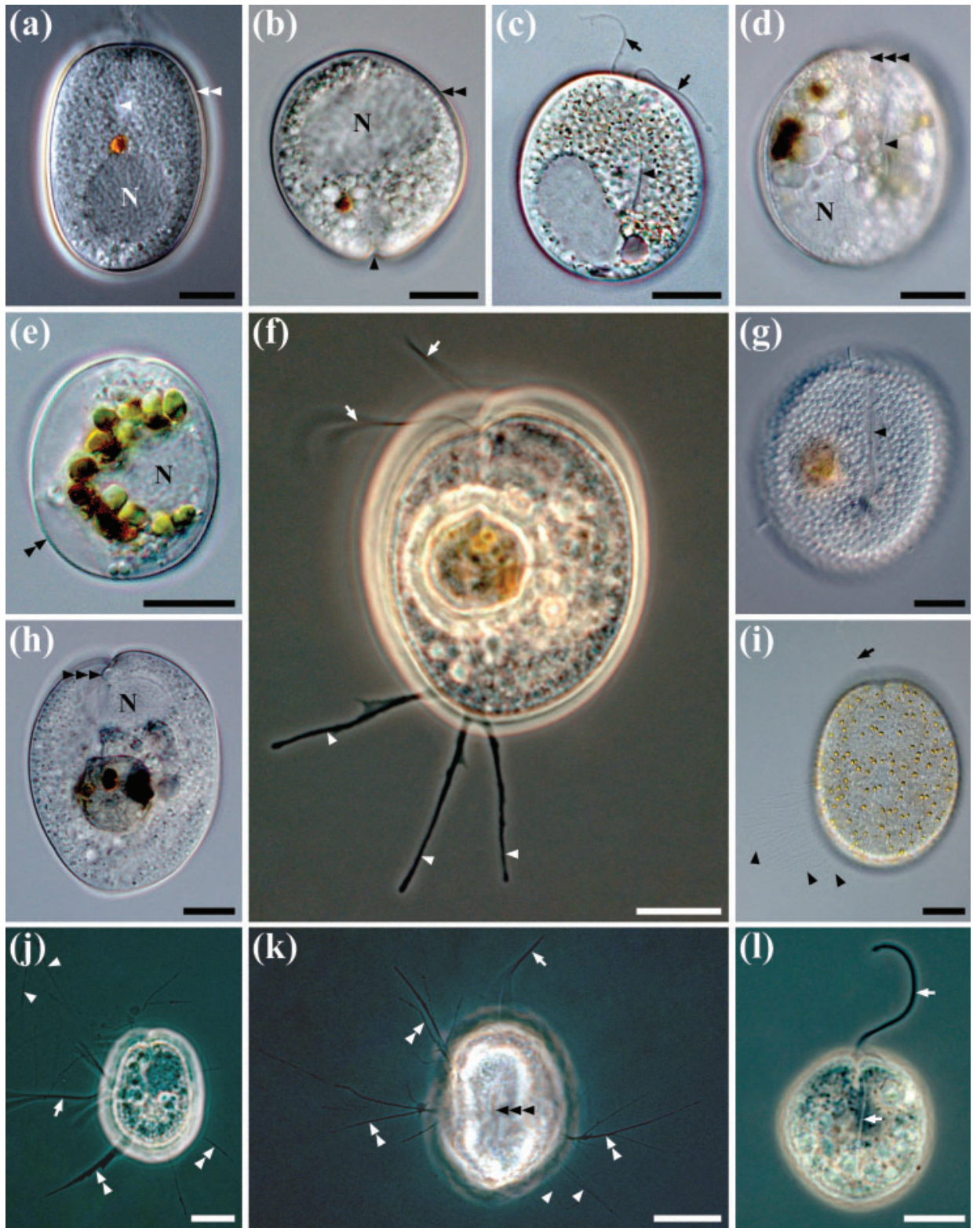

Fig. 2. Light micrographs of the marine benthic cercozoans examined in this study. (a) Protaspis grandis showing an ovoid nucleus $(\mathrm{N})$ at the posterior of the cell, a ventral slit (arrowhead) and a thick cell wall (double arrowhead). (b) Protaspis obliqua showing an anterior nucleus $(\mathrm{N})$, a posterior notch (arrowhead) and a thick cell wall (double arrowhead). (c) Protaspis rotunda sp. nov. showing two flagella (arrows) and a curved slit in the middle of the cell (arrowhead). (d) Protaspis oviformis sp. nov. showing a posterior nucleus $(\mathrm{N})$, a ventral slit (arrowhead) and an anterior protrusion (triple arrowhead). (e) Protaspis oviformis sp. nov. showing a nucleus $(\mathrm{N})$ in the middle of the cell, a thick cell wall (double arrowhead) and numerous ingested green food bodies within the cytoplasm. ( $f$ ) Ventrifissura foliiformis gen. et sp. nov. showing two flagella (arrows) and branched pseudopodia (arrowheads). (g) Ventrifissura artocarpoidea gen. et sp. nov. showing a cell with numerous pointed warts and a ventral slit (arrowhead). (h) Ventrifissura foliiformis gen. et sp. nov. showing a cell with a smooth cell surface, a large food particle, an anterior nucleus $(\mathrm{N})$ and an anterior protrusion (triple arrowhead). This image was taken through the dorsal side and focused at the ventral side of the cell. (i) Verrucomonas bifida gen. et sp. nov. showing an anterior flagellum (arrow), numerous orange warts on the cell surface and ejected extrusomes (arrowheads). (j) Verrucomonas longifila gen. et sp. nov. showing the posterior flagellum (arrow), fine pseudopodia (double arrowheads) and ejected extrusomes (arrowheads). (k) Botuliforma benthica gen. et sp. nov. showing one of two anterior flagella (arrow), ejected extrusomes (arrowheads), very fine and branched pseudopodia (double arrowheads) and a ventral groove (triple arrowhead). (I) Discomonas retusa gen. et sp. nov. showing a prominent long anterior flagellum and a shorter posterior flagellum (arrows). Bars, $10 \mu \mathrm{m}$. 


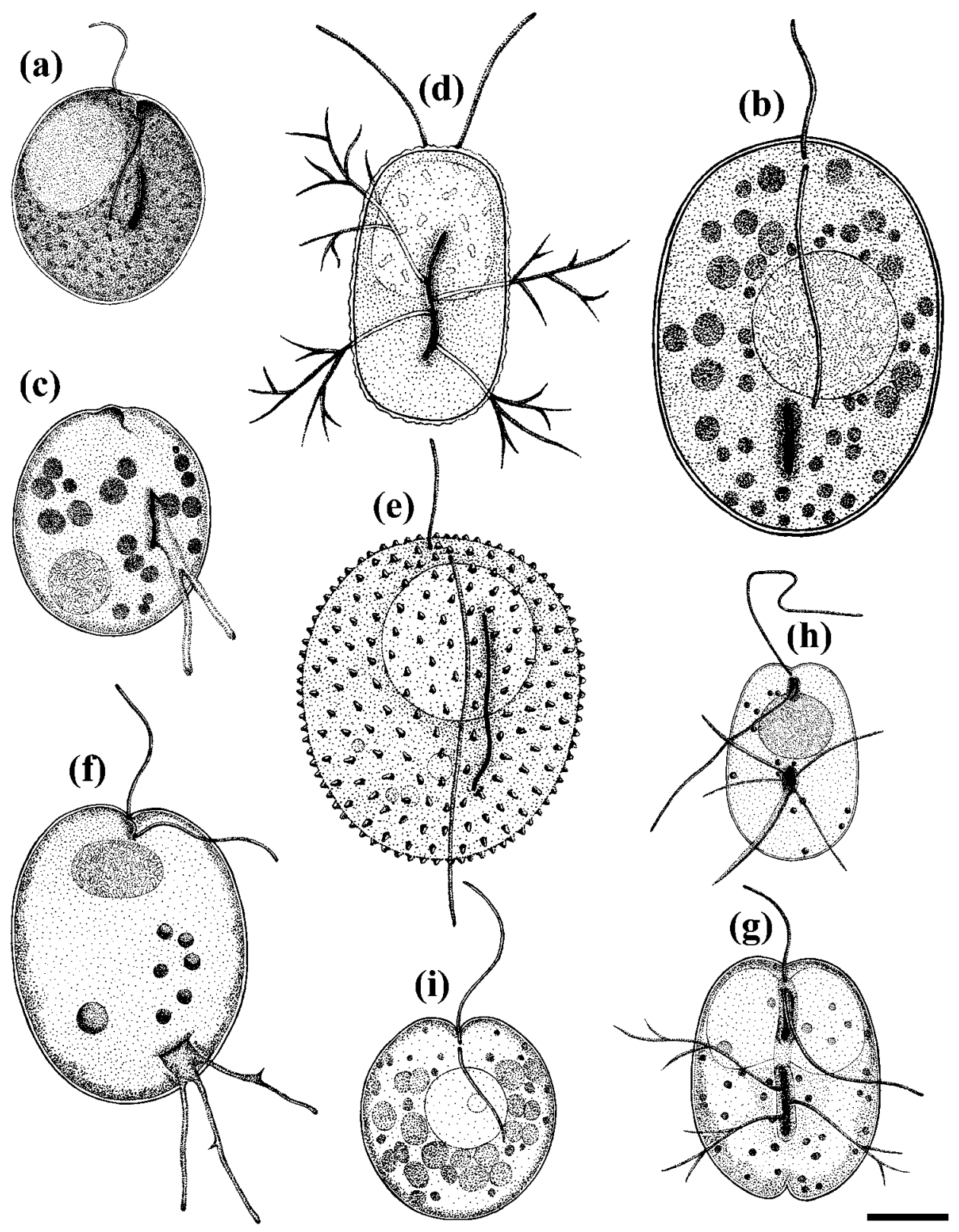

Fig. 3. Diagrammatic line drawings of the nine novel cercozoans found in this study. (a) Protaspis rotunda sp. nov. (b) Protaspis obaniformis sp. nov. (c) Protaspis oviformis sp. nov. (d) Botuliforma benthica gen. et sp. nov. (e) Ventrifissura artocarpoidea gen. et sp. nov. (f) Ventrifissura foliiformis gen. et sp. nov. (g) Verrucomonas bifida gen. et sp. nov. (h) Verrucomonas longifila gen. et sp. nov. (i) Discomonas retusa gen. et sp. nov. Bar, $10 \mu \mathrm{m}$.

\section{The Cryomonadida clade}

Phylogenies inferred from SSU rDNA sequences demonstrated that one previously described species, Protaspis obliqua, and the following three novel species of the genus Protaspis clustered within the Cryomonadida clade, which also contained Protaspis grandis and several recognized species of the genus Cryothecomonas (Figs 4-5). The genus Protaspis currently contains 11 recognized species: $P$. gemmifera, $P$. glans, $P$. grandis, $P$. maior, $P$. metarhiza, $P$. obliqua, $P$. obovata, $P$. simplex, $P$. tanyopsis, $P$. tegere and $P$. verrucosa.

\section{Protaspis rotunda sp. nov. Chantangsi and Leander, 2009}

Size. Cells $25-27 \mu \mathrm{m}$ wide and 30-31 $\mu \mathrm{m}$ long (number of cells observed $>100$ ).

Diagnosis. Cells dorsoventrally flattened and slightly oval to round in outline with smooth surface; uninucleate biflagellate; flagella inserted subapically separated by an anterior protrusion; nucleus is $11 \mu \mathrm{m}$ wide and $15 \mu \mathrm{m}$ long; nucleus is ovoid and located at anterior to the right of 
Table 2. Upper triangular matrix showing the number of nucleotide differences; lower triangular matrix showing the percentage of pairwise sequence divergences between small subunit rRNA genes based on Kimura's two-parameter model

Data are from 17 cercozoans, 11 of which were generated in this study. The sequences were 618 bp in length. Taxa: 1, Cryothecomonas aestivalis (GenBank accession no. AF290541); 2, Cryothecomonas aestivalis (AF290539); 3, Protaspis (ex. Cryothecomonas) longipes (AF290540); 4, Protaspis grandis (DQ303924); 5, Protaspis obliqua isolate 1 (FJ824121); 6, Protaspis obliqua isolate 2 (FJ824122); 7, Protaspis rotunda (FJ824123); 8, Protaspis obaniformis (FJ824124); 9, Protaspis oviformis (FJ824125); 10, Ebria tripartita (DQ303922); 11, Ebria tripartita (DQ303923); 12, Botuliforma benthica (FJ824126); 13, Ventrifissura artocarpoidea (FJ824127); 14, Ventrifissura foliiformis (FJ824128); 15, Verrucomonas bifida (FJ824129); 16, Verrucomonas longifila (FJ824130); 17, Discomonas retusa (FJ824131).

\begin{tabular}{|c|c|c|c|c|c|c|c|c|c|c|c|c|c|c|c|c|c|}
\hline Taxa & 1 & 2 & 3 & 4 & 5 & 6 & 7 & 8 & 9 & 10 & 11 & 12 & 13 & 14 & 15 & 16 & 17 \\
\hline 1. & - & 3 & 21 & 21 & 30 & 29 & 25 & 27 & 19 & 38 & 38 & 33 & 43 & 44 & 74 & 65 & 55 \\
\hline 2. & 0.5 & - & 18 & 18 & 27 & 26 & 22 & 24 & 16 & 35 & 35 & 30 & 42 & 41 & 71 & 64 & 52 \\
\hline 3. & 3.55 & 3.03 & - & 3 & 21 & 20 & 4 & 7 & 2 & 32 & 32 & 28 & 41 & 38 & 70 & 65 & 50 \\
\hline 4. & 3.55 & 3.03 & 0.5 & - & 21 & 20 & 7 & 7 & 4 & 32 & 32 & 28 & 42 & 39 & 70 & 65 & 50 \\
\hline 5. & 5.13 & 4.61 & 3.54 & 3.54 & - & 1 & 25 & 25 & 19 & 37 & 37 & 34 & 46 & 45 & 69 & 66 & 48 \\
\hline 6. & 4.95 & 4.43 & 3.37 & 3.37 & 0.16 & - & 24 & 24 & 18 & 36 & 36 & 33 & 45 & 44 & 70 & 67 & 49 \\
\hline 7. & 4.25 & 3.73 & 0.66 & 1.16 & 4.24 & 4.06 & - & 11 & 6 & 34 & 34 & 30 & 45 & 42 & 72 & 69 & 54 \\
\hline 8. & 4.61 & 4.08 & 1.16 & 1.16 & 4.24 & 4.06 & 1.83 & - & 8 & 38 & 38 & 32 & 46 & 43 & 75 & 70 & 53 \\
\hline 9. & 3.2 & 2.69 & 0.33 & 0.66 & 3.2 & 3.02 & 0.99 & 1.33 & - & 32 & 32 & 28 & 39 & 36 & 69 & 64 & 48 \\
\hline 10. & 6.55 & 6.01 & 5.47 & 5.47 & 6.38 & 6.2 & 5.82 & 6.55 & 5.47 & - & 0 & 16 & 49 & 47 & 67 & 64 & 42 \\
\hline 11. & 6.55 & 6.01 & 5.47 & 5.47 & 6.38 & 6.2 & 5.82 & 6.55 & 5.47 & 0 & - & 16 & 49 & 47 & 67 & 64 & 42 \\
\hline 12. & 5.65 & 5.12 & 4.76 & 4.76 & 5.83 & 5.65 & 5.11 & 5.46 & 4.76 & 2.68 & 2.68 & - & 40 & 41 & 70 & 69 & 48 \\
\hline 13. & 7.46 & 7.28 & 7.09 & 7.27 & 8.02 & 7.83 & 7.82 & 8.02 & 6.72 & 8.6 & 8.6 & 6.92 & - & 27 & 78 & 73 & 61 \\
\hline 14. & 7.62 & 7.08 & 6.53 & 6.71 & 7.81 & 7.63 & 7.25 & 7.44 & 6.17 & 8.18 & 8.18 & 7.08 & 4.59 & - & 76 & 72 & 54 \\
\hline 15. & 13.36 & 12.77 & 12.55 & 12.55 & 12.38 & 12.58 & 12.94 & 13.57 & 12.36 & 11.98 & 11.98 & 12.56 & 14.2 & 13.74 & - & 18 & 80 \\
\hline 16. & 11.59 & 11.41 & 11.59 & 11.59 & 11.81 & 12.01 & 12.38 & 12.6 & 11.4 & 11.42 & 11.42 & 12.38 & 13.19 & 12.95 & 3.03 & - & 77 \\
\hline 17. & 9.7 & 9.14 & 8.75 & 8.75 & 8.38 & 8.57 & 9.5 & 9.33 & 8.38 & 7.28 & 7.28 & 8.38 & 10.85 & 9.48 & 14.56 & 13.98 & - \\
\hline
\end{tabular}

the cell; clear and homogeneous cytoplasm; curved furrow at the subanterior ventral side; locomotion by gliding; found living in a marine interstitial sand habitat. Small-subunit rRNA gene sequence (GenBank accession no. FJ824123). Protaspis rotunda differs from the 11 previously described species of the genus Protaspis in that this species shows a smooth cell surface. Although similar to $P$. oviformis in shape and cell appearance, the nuclear position of $P$. rotunda is at anterior to the right of the cell as opposed to at posterior or sometimes the middle right of the cell in P. oviformis. Cell shapes of $P$. grandis and $P$. obaniformis are oblong rather than the oval shape of $P$. rotunda.

Type locality. Tidal sand-flat at Pachena Beach $\left(48^{\circ} 47^{\prime} \mathrm{N}\right.$ $125^{\circ} 07^{\prime} \mathrm{W}$ ), Vancouver Island, British Columbia, Canada. The organisms were collected in September 2006. This species was also found in June 2007 and June 2008 from the same location.

Iconotype. Figs 1(a), 2(c) and 3(a).

Etymology. The etymology for the specific epithet, L. fem. adj. rotunda round. The specific epithet reflects the round shape of this organism.

\section{Protaspis obaniformis sp. nov. Chantangsi and Leander, 2009}

Size. Cells $30-50 \mu \mathrm{m}$ wide and 50-65 $\mu \mathrm{m}$ long (number of cells observed $=19$ ).
Diagnosis. Cells are broadly elliptical and dorsoventrally flattened; thick wall with smooth surface; uninucleate biflagellate; flagella inserted subapically; nucleus is $18 \mu \mathrm{m}$ wide and $17 \mu \mathrm{m}$ long; circular nucleus with granular (permanently condensed) chromosomes; nucleus is located in the middle of the cell, sometimes towards the anterior of the cell; cytoplasm contains numerous spherical light brownish granules; prominent vertically straight slit at the posterior ventral side; locomotion by gliding; found living in marine interstitial sand habitat. Small-subunit rRNA gene sequence (GenBank accession no. FJ824124). Protaspis obaniformis differs from the 11 previously described species of the genus in that this species possesses an 1/5 cell length posterior slit. Although Protaspis obliqua also shows a ventral furrow/groove at the posterior half of the cell, the posterior notch of $P$. obliqua has never been observed in $P$. obaniformis. In addition, cell shape and cell size of the former (i.e. 10$27 \mu \mathrm{m}$ wide and $8-32 \mu \mathrm{m}$ long) are different from the latter.

Type locality. Tidal sand-flat at Boundary Bay $\left(49^{\circ} 00^{\prime} \mathrm{N}\right.$ $123^{\circ} 02^{\prime} \mathrm{W}$ ), Vancouver, British Columbia, Canada. The organisms were collected in May 2007.

Iconotype. Figs 1(b) and 3(b).

Etymology. The etymology for the specific epithet, Japanese oban is a kind of ancient Japanese coin with a 


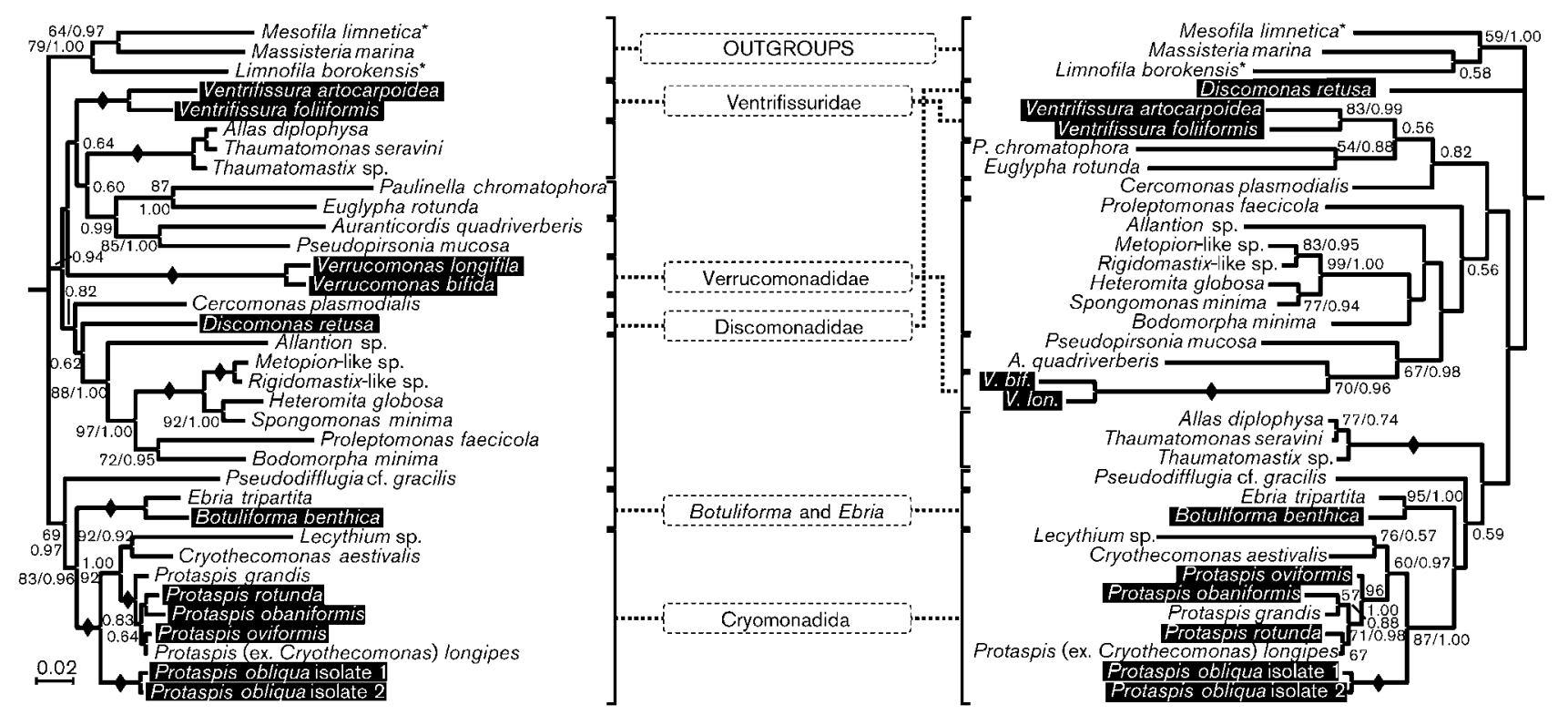

Fig. 4. Comparison between Bayesian phylogenies inferred from the 1617 bp full-length (left; mean $\ln L=-11672.98$ ) and 583 bp 5 '-half barcoding region (right; mean In $L=-4072.00$ ) SSU rDNA sequence alignments of 35 cercozoan taxa; the phylogenetic positions of marine benthic cercozoans studied in this study are highlighted in black boxes. Each tree is a consensus of 36002 trees with the GTR +I+G using four rate categories implemented. Two isolates of Protaspis obliqua are labelled as isolates 1 and 2. Numbers $>0.50$ at the nodes indicate Bayesian posterior probabilities and PhyML bootstrap percentages $>50 \%$. Diamonds represent Bayesian posterior probability of 1.00 and PhyML bootstrap value of $100 \%$. Bar, 0.02 substitutions per site. * Limnofila borokensis was previously misidentified as Gymnophrys cometa (GenBank accession no. AF411284) and Mesofila limnetica was previously referred to as Dimorpha-like sp. (AF411283).

broad oval shape; L. fem. forma shape. The specific epithet, N.L. fem. obaniformis, depicts the shape of this organism, which is similar to an ancient Japanese coin.

\section{Protaspis oviformis sp. nov. Chantangsi and Leander, 2009}

Size. Cell is $25-40 \mu \mathrm{m}$ wide and $30-45 \mu \mathrm{m}$ long (number of cells observed $=36$ ).

Diagnosis. Cells are dorsoventrally flattened and slightly oval to roundish in outline with smooth surface; slightly thick wall; uninucleate cell with an anterior protrusion; nucleus is $8 \mu \mathrm{m}$ wide and $8 \mu \mathrm{m}$ long; nucleus with chromosome appearance is circular in outline and located at posterior or sometimes middle right of the cell; cytoplasm contains numerous spherical brownish, greyish and yellowish granules; vertical ventral slit positioned at the mid anterior end and towards the mid posterior end; finger-like pseudopodia present; locomotion by gliding; found living in marine interstitial sand habitat. Small-subunit rRNA gene sequence (GenBank accession no. FJ824125). Protaspis oviformis differs from the 11 previously described species of the genus in that this species possesses a very oval shape and smooth cell surface. Nuclear position of this species is located differently from its close relatives, $P$. grandis (i.e. posterior at the middle of the cell) and P. rotunda (i.e. anterior to the right of the cell). Unlike P. obaniformis, which possesses a posterior ventral slit, this structure of $P$. oviformis is located at the mid anterior end and towards the mid posterior end of the cell.

Type locality. Tidal sand-flat at Boundary Bay $\left(49^{\circ} 00^{\prime} \mathrm{N}\right.$ $\left.123^{\circ} 02^{\prime} \mathrm{W}\right)$, Vancouver, British Columbia, Canada. The organisms were collected in March 2007.

Iconotype. Figs 1(c), 2(d-e) and 3(c).

Etymology. The etymology for the specific epithet, L. neut. n. ovum egg; L. fem. forma shape. The specific epithet reflects the shape of this organism.

\section{Protaspis longipes (Schnepf \& Kühn, 2000) Chantangsi and Leander comb. nov.}

Basionym: Cryothecomonas longipes Schnepf and Kühn, 2000.

\section{The Botuliformidae lineage}

Phylogenies inferred from SSU rDNA sequences demonstrated that one new genus/species clustered strongly with the 'Ebriid' clade comprising an Ebria tripartita sequence and an environmental sequence (Figs 4-5). 


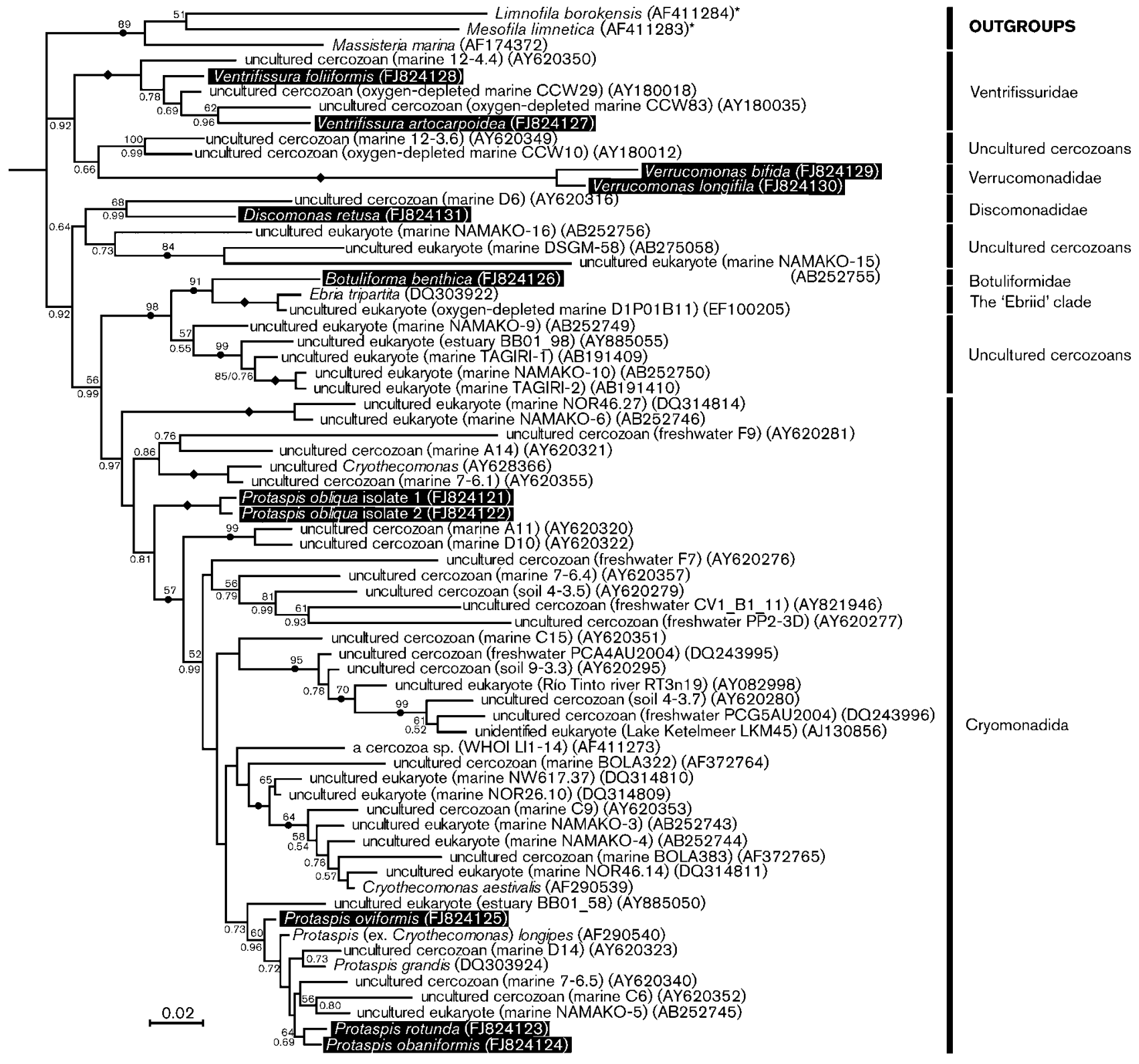

Fig. 5. Bayesian phylogeny deduced from 923 bp of SSU rDNA sequences of 67 cercozoan taxa including several sequences derived from environmental studies; the phylogenetic positions of marine benthic cercozoans examined in this study are highlighted in black boxes. The tree (mean $\ln L=-7530.23$ ) is a consensus of 36002 trees with the GTR $+\mathrm{I}+\mathrm{G}$ using four rate categories implemented. Numbers $>0.50$ at the nodes indicate Bayesian posterior probabilities and PhyML bootstrap percentages $>50 \%$. Black circles represent Bayesian posterior probability of 1.00. Black diamonds represent Bayesian posterior probability of 1.00 and PhyML bootstrap value of $100 \%$. Bar, 0.02 substitutions per site. *Limnofila borokensis was previously misidentified as Gymnophrys cometa (AF411284) and Mesofila limnetica was previously referred to as Dimorpha-like sp. (AF411283).

\section{Genus Botuliforma gen. nov. Chantangsi and Leander, 2009}

Diagnosis. Cells are oblong; slightly thick wall with rough surface; uninucleate biflagellate; flagella inserted subapically; large nucleus with granular (permanently condensed) chromosomes located at anterior end of the cell; colourless cytoplasm; ventral furrow present; very fine filopodia observed; extrusomes present; locomotion by rotational swimming; found living in marine interstitial sand habitats.

Type species. Botuliforma benthica.

Etymology. The etymology for the generic name, L. masc. n. botulus sausage; L. fem. forma shape. The genus name reflects the sausage shape of the type species. 


\section{Botuliforma benthica sp. nov. Chantangsi and Leander, 2009}

Size. Cell is about $20 \mu \mathrm{m}$ wide and $35 \mu \mathrm{m}$ long (number of cells observed $=51$ ).

Diagnosis. Structure as described for the genus; nucleus is $12 \mu \mathrm{m}$ wide and $15 \mu \mathrm{m}$ long; large nucleus is subspherical in outline and located at the anterior end of the cell; aggregation of cells forming a swimming spherical ball observed. Small-subunit rRNA gene sequence (GenBank accession no. FJ824126).

Type locality. Tidal sand-flat at Pachena Beach $\left(48^{\circ} 47^{\prime} \mathrm{N}\right.$ $125^{\circ} 07^{\prime} \mathrm{W}$ ), Vancouver Island, British Columbia, Canada. The organisms were collected in June 2007 and June 2008.

Iconotype. Figs 1(d), 2(k) and 3(d).

Etymology. The etymology for the specific epithet, N.L. benthica of the benthos. The specific epithet reflects the natural habitat of this organism.

\section{The Ventrifissuridae clade}

Phylogenies inferred from SSU rDNA gene sequences demonstrated that one new genus and two new species clustered together with several environmental sequences and formed the Ventrifissuridae clade (Figs 4-5).

\section{Genus Ventrifissura gen. nov. Chantangsi and Leander, 2009}

Diagnosis. Cells are broadly obovate and dorsoventrally flattened; cells either with smooth surfaces or with numerous pointed warts; uninucleate biflagellate; flagella inserted subapically with or without an anterior protrusion; circular to oblong-shaped nucleus located at the anterior end of the cell; colourless cytoplasm; ventral furrow present; filopodia observed; extrusomes present; locomotion by gliding; found living in marine interstitial sand habitat.

Type species. Ventrifissura artocarpoidea.

Etymology. The etymology for the generic name, L. masc. ventris belly; L. fem. fissura crack, cleft, chink. The genus name reflects the morphological feature of members within this genus of having a slit on the ventral side.

\section{Ventrifissura artocarpoidea sp. nov. Chantangsi and Leander, 2009}

Size. Cell is about $35-36 \mu \mathrm{m}$ wide and $43-45 \mu \mathrm{m}$ long (number of cells observed $=$ three).

Diagnosis. Cells are broadly obovate and dorsoventrally slightly flattened; numerous pointed warts distributed evenly over the cell surface; uninucleate biflagellate; flagella inserted subapically without a protrusion; circular nucleus located at the anterior end of the cell, sometimes toward the left side; colourless cytoplasm, sometimes with food particles; ventral furrow present; locomotion by gliding; found living in marine interstitial sand habitat. Small-subunit rRNA gene sequence (GenBank accession no. FJ824127).

Type locality. Tidal sand-flat at Boundary Bay $\left(49^{\circ} 00^{\prime} \mathrm{N}\right.$ $\left.123^{\circ} 02^{\prime} \mathrm{W}\right)$, Vancouver, British Columbia, Canada. The organisms were collected in May 2007.

Iconotype. Figs 1(e), 2(g) and 3(e).

Etymology. The etymology for the specific epithet, N.L. masc. artocarpus a genus of breadfruit; L. fem. -oidea suffix denoting resembling. The specific epithet reflects the shape of this organism, which is similar to a breadfruit.

\section{Ventrifissura foliiformis sp. nov. Chantangsi and Leander, 2009}

Size. Cell is about $30-35 \mu \mathrm{m}$ wide and $40-47 \mu \mathrm{m}$ long (number of cells observed $>100$ ).

Diagnosis. Cells are broadly obovate and (extremely) dorsoventrally flattened with a smooth cell surface; uninucleate biflagellate; flagella inserted subapically between an anterior protrusion; nucleus is $15 \mu \mathrm{m}$ wide and $10 \mu \mathrm{m}$ long; oblong nucleus with granular appearance located at the anterior end of the cell, sometimes toward the right side; colourless cytoplasm, sometimes with food particles; small clear vacuoles present; ventral furrow present; filopodia observed; extrusomes present; locomotion by gliding; found living in marine interstitial sand habitat. Small-subunit rRNA gene sequence (GenBank accession no. FJ824128).

Type locality. Tidal sand-flat at Boundary Bay $\left(49^{\circ} 00^{\prime} \mathrm{N}\right.$ $\left.123^{\circ} 02^{\prime} \mathrm{W}\right)$, Vancouver, British Columbia, Canada. The organisms were collected in May 2007.

Iconotype. Figs 1(f), 2(f), 2(h) and 3(f).

Etymology. The etymology for the specific epithet, L. neut. folium leaf; L. fem. forma shape. The specific epithet reflects the shape of this organism, which is flattened like a leaf.

\section{The Verrucomonadidae clade}

Phylogenies inferred from SSU rDNA sequences demonstrated that one new genus and two novel species clustered together and formed the Verrucomonadidae clade (Figs 4-5).

\section{Genus Verrucomonas gen. nov. Chantangsi and Leander, 2009}

Diagnosis. Cells are dorsoventrally flattened and with a rough surface; coloured warts ranging from yellowish to 
red, brownish, and golden observed on cell surface; uninucleate biflagellate; flagella inserted subapically; nucleus is located at the anterior end of the cell; colourless cytoplasm; ventral furrow present; anterior and posterior notches sometimes present; filopodia observed; extrusomes present; locomotion by gliding; found living in marine interstitial sand habitat.

Type species. Verrucomonas bifida.

Etymology. The etymology for the generic name, L. fem. verruca wart; L. fem. monas a unit (which refers to the flagellate). The genus name reflects the morphological feature of having coloured warts on the cell surface.

\section{Verrucomonas bifida sp. nov. Chantangsi and Leander, 2009}

Size. Cell is about $17-25 \mu \mathrm{m}$ wide and $30-34 \mu \mathrm{m}$ long (number of cells observed $>100$ ).

Diagnosis. Cells are dorsoventrally flattened with a rough surface; coloured warts ranging from yellowish to red, brownish, and golden observed on cell surface; uninucleate biflagellate; flagella inserted subapically; bilobed nucleus, $20 \mu \mathrm{m}$ wide and $13 \mu \mathrm{m}$ long, located at the anterior of the cell; colourless cytoplasm; ventral furrow present; anterior and posterior notches sometimes present; fine filopodia observed; extrusomes present; locomotion by gliding; found living in marine interstitial sand habitat. Small-subunit rRNA gene sequence (GenBank accession no. FJ824129).

Type locality. Tidal sand-flat at Boundary Bay $\left(49^{\circ} 00^{\prime} \mathrm{N}\right.$ $\left.123^{\circ} 02^{\prime} \mathrm{W}\right)$, Vancouver, British Columbia, Canada. The organisms were collected in May 2007.

Iconotype. Figs 1(g), 2(i) and 3(g).

Etymology. The etymology for the specific epithet, L. fem. bifida two-cleft. The specific epithet reflects the shape of the organism's nucleus, which seems to be divided into two parts.

\section{Verrucomonas longifila sp. nov. Chantangsi and Leander, 2009}

Size. Cell is about $15-20 \mu \mathrm{m}$ wide and $23-37 \mu \mathrm{m}$ long (number of cells observed $=11$ ).

Diagnosis. Cells are dorsoventrally flattened with a rough surface; yellowish and reddish warts observed on cell surface; uninucleate biflagellate; flagella inserted subapically; elliptical nucleus with granular appearance, $8 \mu \mathrm{m}$ wide and $5 \mu \mathrm{m}$ long, located at anterior end of the cell; colourless cytoplasm; ventral furrow present; anterior and posterior notches sometimes present; fine filopodia observed; extrusomes present; locomotion by gliding; found living in marine interstitial sand habitat. Small-subunit rRNA gene sequence (GenBank accession no. FJ824130).
Type locality. Tidal sand-flat at Spanish Banks $\left(49^{\circ} 16^{\prime} \mathrm{N}\right.$ $\left.123^{\circ} 14^{\prime} \mathrm{W}\right)$, Vancouver, British Columbia, Canada. The organisms were collected in April 2007.

Iconotype. Figs 1(h), 2(j) and 3(h).

Etymology. The etymology for the specific epithet, L. masc. longus long; L. fem. fila thread. The specific epithet reflects the longer flagella of this organism in comparison with those of its close relative, Verrucomonas bifida.

\section{The Discomonadidae clade}

Phylogenies inferred from SSU rDNA sequences demonstrated that one novel genus/species clustered with an environmental sequence and formed the Discomonadidae clade (Figs 4-5).

\section{Genus Discomonas gen. nov. Chantangsi and Leander, 2009}

Diagnosis. Cells are disc-shaped and dorsoventrally flattened; uninucleate biflagellate; flagella inserted subapically; nucleus is located in the middle-anterior of the cell; anterior notch present; colourless cytoplasm, sometimes with food particles at the posterior end of the cell; locomotion by gliding; found living in marine interstitial sand habitat.

Type species. Discomonas retusa.

Etymology. The etymology for the generic name, L. masc. discus flat, circular plate; L. fem. monas a unit (which refers to the flagellate). The genus name reflects the shape of this organism.

\section{Discomonas retusa sp. nov. Chantangsi and Leander, 2009}

Size. Cell is about $25 \mu \mathrm{m}$ wide and $25 \mu \mathrm{m}$ long (number of cells observed $=$ five).

Diagnosis. Structure as described for the genus; nucleus is $9 \mu \mathrm{m}$ wide and $9 \mu \mathrm{m}$ long; discoidal nucleus with central nucleolus located at the middle-anterior of the cell. Smallsubunit rRNA gene sequence (GenBank accession no. FJ824131).

Type locality. Tidal sand-flat at Boundary Bay $\left(49^{\circ} 00^{\prime} \mathrm{N}\right.$ $\left.123^{\circ} 02^{\prime} \mathrm{W}\right)$, Vancouver, British Columbia, Canada. The organisms were collected in May 2007.

Iconotype. Figs 1(i), 2(l) and 3(i).

Etymology. The etymology for the specific epithet, L. fem. retusa notched at the apex. The specific epithet reflects the notched appearance at the anterior end of the organism. 


\section{DNA barcoding marine benthic cercozoans}

DNA analyses based on the K2P model of 1798 bp full-length and $618 \mathrm{bp}$ barcoding regions of SSU rDNA sequences of 17 benthic cercozoans showed relatively similar mean values of sequence divergences, $7.57 \%$ and $6.98 \%$, respectively. Analyses of the barcoding region of isolates of three species, including Cryothecomonas aestivalis, Ebria tripartita and Protaspis obliqua, showed low intraspecific sequence variation and only a few nucleotide differences (Table 2). In general, intergeneric sequence divergences between examined genera were quite high (Table 2). It is also significant to note that Cryothecomonas longipes showed lower sequence divergences and fewer nucleotide differences from Protaspis grandis (Fig. 2a) than from Cryothecomonas aestivalis, which is consistent with the molecular phylogenetic data (Figs 4-5). Moreover, two isolates of Protaspis obliqua (Fig. 2b) showed high sequence divergences and large numbers of nucleotide differences from the other species/morphotypes currently recognized as 'Protaspis'.

\section{Molecular phylogenetic analyses of marine benthic cercozoans}

Phylogenies deduced from the $1617 \mathrm{bp}$ full-length and $583 \mathrm{bp}$ barcoding region of SSU rDNA sequences of 35 cercozoan taxa, including representatives from several major cercozoan subgroups, showed very similar tree topologies (Fig. 4). Protaspis obliqua and three new species of Protaspis, namely $P$. rotunda, $P$. obaniformis and $P$. oviformis, clustered within the Cryomonadida clade, which currently contains three genera - Cryothecomonas, Lecythium and Protaspis (Fig. 4). However, P. obliqua was positioned distantly from the other species of the genus Protaspis, and Cryothecomonas longipes was placed within the main Protaspis lineage with very strong statistical support (Figs 4-5). The nearest sister group to the order Cryomonadida was a clade consisting of Botuliforma benthica gen. et sp. nov., Ebria tripartita and several undescribed cercozoans derived from environmental DNA surveys (Fig. 5). The remaining five species described here - namely Ventrifissura artocarpoidea gen. et sp. nov., Ventrifissura foliiformis gen. et sp. nov., Verrucomonas bifida gen. et sp. nov., Verrucomonas longifila gen. et sp. nov., and Discomonas retusa gen. et sp. nov. - branched with different undescribed cercozoans derived from environmental DNA surveys, forming three different clades with morphological features that were unknown prior to this study.

\section{DISCUSSION}

\section{Hidden diversity of marine benthic cercozoans}

Marine planktonic and benthic habitats house a large number of microeukaryotic lineages (Massana \& Pedrós-Alió, 2008; Park et al., 2008). The actual biodiversity in benthic environments, however, is not well understood because studies on these habitats are relatively infrequent compared with studies on planktonic environments (Bass \& Cavalier-Smith, 2004;
Chantangsi et al., 2008; Fenchel, 1987; Hondeveld et al., 1992; Hoppenrath \& Leander, 2006a; Lee, 2008). Nonetheless, several studies based on environmental PCR analyses of SSU rDNA have shown that cercozoans, such as members of the genera Auranticordis, Cercomonas, Massisteria, Metopion, Metromonas, Protaspis and Thaumatomonas, are major components of benthic habitats (Al Qassab et al., 2002; Bass \& Cavalier-Smith, 2004; Chantangsi et al., 2008; Hoppenrath \& Leander, 2006a; Myl'nikov \& Karpov, 2004; Park et al., 2008). The genus Protaspis, in particular, has been reported from several aquatic and terrestrial environments worldwide (Auer \& Arndt, 2001; Ekelund \& Patterson, 1997; Hoppenrath \& Leander, 2006a; Larsen \& Patterson, 1990; Lee et al., 2003, 2005; Lee \& Patterson, 2000; Vørs, 1993).

\section{The current composition of the genus Protaspis}

The genus Protaspis was originally described by Skuja (1939) and currently contains 11 recognized species: $P$. gemmifera, P. glans, P. grandis, P. maior, P. metarhiza, P. obliqua, $P$. obovata, $P$. simplex, $P$. tanyopsis, $P$. tegere and $P$. verrucosa. However, our study shows the actual diversity of the group to be far greater. We have assigned three novel species $-P$. rotunda, $P$. obaniformis and $P$. oviformis - to this genus. These novel flagellates share several common generic features with the type species: (i) a rigid cell body with two heterodynamic flagella (at least in the first two species), (ii) both flagella insert subapically on the ventral side of the cell (at least in the first two species), and (iii) cells are dorsoventrally flattened and possess a ventral slit from which pseudopodia can be protruded (Hoppenrath \& Leander, 2006a; Myl'nikov \& Karpov, 2004; Skuja, 1939). However, the three novel members of the genus Protaspis described here did not possess the specific cell shapes and diagnostic features found in the previously recognized species.

Our molecular phylogenetic analyses demonstrated that the three novel species of the genus Protaspis grouped strongly with $P$. grandis. However, two isolates of Protaspis obliqua, whose SSU rDNA sequences were sequenced in this study, were positioned very distantly from the other members of the genus Protaspis in our molecular phylogenetic analyses; this result was consistent with the large number of nucleotide differences between $P$. obliqua and the other Protaspis sequences and led us to doubt the taxonomic status of $P$. obliqua. These data also suggest that a great deal of genetic diversity is hidden at the morphological level (Weisse, 2008). However, further comparative investigations of ultrastructural features in members of the genus Protaspis (especially the type species $P$. glans) might demonstrate differences that are consistent with the molecular phylogenetic data and lead to the future taxonomic reassignment of $P$. obliqua.

\section{Cryothecomonas longipes is more closely related to the genus Protaspis sensu stricto}

The genus Cryothecomonas was shown to be the closest relative of the genus Protaspis based on molecular 
phylogenetic evidence and some ultrastructural features (Hoppenrath \& Leander, 2006a; Thomsen et al., 1991). Six species of the genus Cryothecomonas, namely C. aestivalis, C. armigera, C. inermis, C. longipes, C. scybalophora and C. vesiculata, have been described thus far and only two of them, C. aestivalis and C. longipes, have had their SSU rDNA sequenced (Drebes et al., 1996; Kühn et al., 2000; Schnepf \& Kühn, 2000; Thomsen et al., 1991). Our phylogenetic analyses demonstrated a closer relationship between $C$. longipes and the genus Protaspis (excluding $P$. obliqua) than to $C$. aestivalis, which was consistent with previous results (Hoppenrath \& Leander, 2006a).

Thomsen et al. (1991) established Cryothecomonas as a new genus on the basis of differences between these species and the previously established genus Protaspis, such as the configuration of the flagellar apparatus and the location of the cell slit/groove (Thomsen et al., 1991). Flagella are homodynamic and inserted apically in members of the genus Cryothecomonas, whereas members of the genus Protaspis have heterodynamic flagella inserted subapically (Skuja, 1939; Thomsen et al., 1991). The cell slit/groove, where pseudopodia emerge, is located posterior-laterally in the genus Cryothecomonas and ventral-medially in the genus Protaspis (Skuja, 1939; Thomsen et al., 1991). Ultrastructural studies on the latest member of the genus Cryothecomonas, namely C. longipes, demonstrated morphological differences between this species and the other four species in the genus Cryothecomonas, which were all described together when this genus was first established (Thomsen et al., 1991). For instance, C. longipes possesses heterodynamic flagella; the anterior flagellum is inserted apically and the posterior flagellum is inserted subapically. Moreover, the ventral slit in C. longipes and members of the genus Protaspis is located on the ventral side of the cell. If flagellar orientation and the location of longitudinal groove were the key features that prompted Thomsen et al. (1991) to separate the genus Cryothecomonas from Protaspis, then $C$. longipes should not belong to the former genus. Several ultrastructural features shared by $C$. longipes and $P$. grandis have also been demonstrated, such as the presence of a multilayered cell wall, a nucleus with a prominent nucleolus and condensed chromosomes, structurally identical extrusomes and flagellar pits with distinctive funnels (Hoppenrath \& Leander, 2006a; Schnepf \& Kühn, 2000). All of these data are consistent with our molecular phylogenetic analyses that showed $C$. longipes within the main Protaspis clade. For these reasons, we have transferred C. longipes to the genus Protaspis: P. longipes comb. nov. (see Results section).

\section{The benthic Botuliforma benthica gen. et sp. nov. is closely related to the planktonic Ebria tripartita}

We have discovered a benthic swimming flagellate, namely Botuliforma benthica gen. et sp. nov., that is the nearest sister lineage to the clade consisting of Ebria tripartita and environmental sequence GenBank accession no. EF100205 as inferred from SSU rDNA sequences (Fig. 5). Interestingly, the environmental sequence was generated from the upper $2 \mathrm{~cm}$ of oxygen-depleted intertidal marine sediments, which is nearly identical to the habitat where we collected $B$. benthica gen. et sp. nov. The distinctively different DNA sequences, habitats and morphological features of Botuliforma and Ebria led us to establish a new genus for this novel benthic organism. The 'Ebriida' clade was previously shown to be a member of the Cercozoa and a close sister lineage to the Cryomonadida in SSU rDNA phylogenies (Hoppenrath \& Leander, 2006b). Although morphological similarities between representatives of these two clades were not initially obvious, shared features have been demonstrated at the ultrastructural level (Hoppenrath \& Leander, 2006b). Members of the genera Ebria, Cryothecomonas and Protaspis all share two unequal flagella, a nucleus with a prominent nucleolus and permanently condensed chromosomes, tubular mitochondrial cristae (at least in the last two genera) and feeding by means of pseudopodia (Hargraves, 2002; Hoppenrath \& Leander, 2006a, b; Thomsen et al., 1991). All current members of the Cryomonadida (genera Cryothecomonas, Lecythium and Protaspis) possess a test, layered wall or theca around the cells; in contrast, members of the genus Ebria possess a naked cell with a fine layer of fibrillar material lying outside the plasma membrane and an internal siliceous skeleton (Hargraves, 2002).

The combination of features in B. benthica gen. et sp. nov. appears to be transitional between ebriids and cryomonads. For example, $B$. benthica has a thick and rough wall that might be homologous to the multilayered cell walls of members of the genera Cryothecomonas and Protaspis. In addition, a prominent nucleus with condensed chromosomes, fine pseudopodia and extrusomes were easily observed in $B$. benthica under LM (Figs $1 \mathrm{~d}, 2 \mathrm{k}$ ), and these features are also found in members of the genera Cryothecomonas and Protaspis (Drebes et al., 1996; Hoppenrath \& Leander, 2006a; Schnepf \& Kühn, 2000; Thomsen et al., 1991). Although ultrastructural data are currently unavailable for $B$. benthica gen. et sp. nov., the close relationship between this lineage and E. tripartita is very robust in molecular phylogenies inferred from SSU rDNA. Therefore, transmission electron microscopy of $B$. benthica gen. et sp. nov. might demonstrate the existence of inconspicuous siliceous skeletal elements that are homologous with ebriids.

\section{The cellular identities of previously undescribed cercozoans}

We established three new genera in addition to Botuliforma gen. nov., namely Discomonas gen. nov., Ventrifissura gen. nov. and Verrucomonas gen. nov., on the basis of their very distant molecular phylogenetic positions inferred from SSU rDNA sequences (Figs 4-5). Our phylogenetic analyses placed two novel species of the genus Ventrifissura, $V$. artocarpoidea and $V$. foliiformis, within a very distinct clade consisting of three environmental sequences derived from 
marine environments: GenBank accession nos AY180018, AY180035 and AY620350 (Bass \& Cavalier-Smith, 2004; Stoeck \& Epstein, 2003). The two novel species of the genus Verrucomonas were separated from the other cercozoans by very long branch-lengths (Fig. 5). This Verrucomonadidae clade clustered weakly with two environmental sequences also obtained from marine environments, GenBank accession nos AY180012 and AY620349 (Bass \& Cavalier-Smith, 2004; Stoeck \& Epstein, 2003), and this more inclusive clade formed the nearest sister group to the Ventrifissuridae clade (Fig. 5). Analyses by Bass \& Cavalier-Smith (2004) showed that several of these environmental sequences (e.g. uncultured cercozoan GenBank accession nos AY620349 and AY620350) are members of the Tectofilosida, and the morphological features we describe here help establish the cellular identities for some of the environmental sequence clades contained therein.

The SSU rDNA sequence of Discomonas gen. nov. formed the nearest sister lineage to uncultured cercozoan GenBank accession no. AY620316 (Fig. 5). Bass \& Cavalier-Smith (2004) recognized this environmental sequence as an undescribed member of 'Basal Group T', which branched closely with thaumatomonads. Our analyses of two different datasets, however, showed incongruent phylogenetic positions for Discomonas gen. nov. Analyses of the 923 bp dataset showed Discomonas gen. nov. branching with environmental sequence AY620316, and analyses of the $1617 \mathrm{bp}$ dataset showed Discomonas gen. nov. branching next to the Cercomonadida lineage (e.g. Cercomonas plasmodialis; Fig. 4). This incongruence was also observed by Bass \& Cavalier-Smith (2004); they reported that AY620316 can sometimes be a sister lineage to the Metopiida and a few other sequences recognized by them as 'Novel Clade 6'. However, these relationships were recovered with only weak statistical support. Although these organisms need to be revisited in the future using alternative molecular markers, our study provides morphological information for Discomonas gen. nov. that sheds light on the probable cellular identity of AY620316 and 'Basal Group T' .

Our study has shown morphological evidence for at least two previously uncharacterized clades belonging to the Tectofilosida and helps substantiate the establishment of the Thecofilosea, which currently contains Tectofilosida and Cryomonadida (Bass \& Cavalier-Smith, 2004). However, the original diagnosis for Tectofilosida by Cavalier-Smith \& Chao (2003) [i.e. uninucleate cell surrounded by an organic flexible tectum or rigid test with one or two apertures for filopodia, sometimes including foreign mineral particles (agglutinated); cilia or silica scales absent; tubular mitochondrial cristae] should be amended by adding 'flagella present' as both the genera Ventrifissura and Verrucomonas possess flagella and are now shown to be members of the Tectofilosida.

\section{Barcoding marine benthic cercozoans}

DNA sequences can be effectively used as a diagnostic tool for the identification of species, an approach known as
'DNA barcoding' (Hebert et al., 2003a, b). This general approach is starting to be used extensively for assessing the diversity of microeukaryotes having limited morphological details for species discrimination (Barth et al., 2006; Chantangsi et al., 2007; Lynn \& Strüder-Kypke, 2006; Saunders, 2005; Scicluna et al., 2006). Accordingly, one primary aim of our study was to help demonstrate the potential of the $618 \mathrm{bp}$ SSU rDNA sequence as DNA barcode for identifying marine benthic cercozoans and possibly other cercozoans. Bass \& Cavalier-Smith (2004) previously designed phylum-specific primers covering the 618 bp barcoding region for SSU rDNA, which facilitated PCR amplification of the gene sequences in the group of cercozoans we investigated here.

In our analyses, different isolates of E. tripartita and $P$. obliqua showed no and one nucleotide differences in their $618 \mathrm{bp}$ barcoding regions, respectively. This result helped demonstrate the reliability of the DNA barcoding region for species identification. In contrast, two different isolates of Cryothecomonas aestivalis showed $0.5 \%$ sequence divergence (three nucleotide differences), which was equal to the divergence value between $P$. grandis and $P$. longipes (ex. Cryothecomonas longipes) (Table 2). Therefore, if $P$. grandis and $P$. longipes constitute separate species as clearly shown by morphological and molecular evidence, then the two isolates of $C$. aestivalis could also be justifiably established as two (cryptic) species on the basis of this molecular marker. It turns out that the possibility of cryptic species within $C$. aestivalis has already been mentioned by Kühn et al. (2000) when they found a relatively high number of nucleotide differences between two morphologically indistinguishable strains of this 'species'. These results, therefore, also demonstrate the utility of the DNA barcoding region for discovering and delimiting cryptic species. Moreover, because the $618 \mathrm{bp}$ barcoding region gene produced very similar phylogenetic tree topologies to those derived from the full length of the gene (Fig. 4), this short barcoding region can also help systematists infer the broader genealogical relationships of cercozoans.

The high copy number of the SSU rRNA gene in eukaryotic nuclear genomes facilitates the barcoding of isolated microeukaryotes even when very limited numbers of organisms can be obtained. Our study has shown that this approach is very useful for exploring the biodiversity of uncultured microeukaryotes; most of the SSU rDNA sequences reported here were derived from a small number of uncultured cells per DNA extraction, and in several cases, we acquired SSU rDNA sequences from only one uncultured cell, which was manually isolated from the ocean. Our study not only highlights the cryptic diversity of marine benthic cercozoans, which is extremely problematic for the non-specialist, but also demonstrates an alternative approach for species identification using the DNA barcoding principle. Moreover, we have provided morphological data for several cercozoan subgroups that were previously known only from environmental DNA surveys. Overall, these data provide insights into the cellular identities of 
uncultured and undescribed cercozoans that help advance our understanding of cercozoan biodiversity in marine benthic ecosystems.

\section{ACKNOWLEDGEMENTS}

We thank K. Tangthongchaiwiriya for illustrating all nine novel cercozoans (Fig. 3). C. C. was supported by a national scholarship awarded by the Cooperative Research Network (CRN), Government of Thailand. This work was supported by grants to B.S. L. from the National Science and Engineering Research Council of Canada (NSERC 283091-04) and the Canadian Institute for Advanced Research, Program in Integrated Microbial Biodiversity.

\section{REFERENCES}

Al Qassab, S., Lee, W. J., Murray, S. \& Patterson, D. J. (2002). Flagellates from stromatolites and surrounding sediments in Shark Bay, Western Australia. Acta Protozool 41, 91-144.

Auer, B. \& Arndt, H. (2001). Taxonomic composition and biomass of heterotrophic flagellates in relation to lake trophy and season. Freshw Biol 46, 959-972.

Barth, D., Krenek, S., Fokin, S. I. \& Berendonk, T. U. (2006). Intraspecific genetic variation in Paramecium revealed by mitochondrial cytochrome $c$ oxidase I sequences. J Eukaryot Microbiol 53, 2025.

Bass, D. \& Cavalier-Smith, T. (2004). Phylum-specific environmental DNA analysis reveals remarkably high global biodiversity of Cercozoa (Protozoa). Int J Syst Evol Microbiol 54, 2393-2404.

Berney, C., Fahrni, J. \& Pawlowski, J. (2004). How many novel eukaryotic 'kingdoms'? Pitfalls and limitations of environmental DNA surveys. BMC Biol 2, 13.

Cavalier-Smith, T. (1998a). A revised six-kingdom system of life. Biol Rev Camb Philos Soc 73, 203-266.

Cavalier-Smith, T. (1998b). Neomonada and the origin of animals and fungi. In Evolutionary Relationships Among Protozoa, pp. 375-407. Edited by G. H. Coombs, K. Vickerman, M. A. Sleigh \& A. Warren. London: Kluwer Academic Publishers.

Cavalier-Smith, T. \& Chao, E. E. (2003). Phylogeny and classification of Phylum Cercozoa (Protozoa). Protist 154, 341-358.

Chantangsi, C., Lynn, D. H., Brandl, M. T., Cole, J. C., Hetrick, N. \& Ikonomi, P. (2007). Barcoding ciliates: a comprehensive study of 75 isolates of genus Tetrahymena. Int J Syst Evol Microbiol 57, 2412-2425.

Chantangsi, C., Esson, H. J. \& Leander, B. S. (2008). Morphology and molecular phylogeny of a marine interstitial tetraflagellate with putative endosymbionts: Auranticordis quadriverberis n. gen. et $\mathrm{sp}$. (Cercozoa). BMC Microbiol 8, 123.

Cummings, D. J. (1992). Mitochondrial genomes of the ciliates. Int Rev Cytol 141, 1-64.

Drebes, G., Kühn, S. F., Gmelch, A. \& Schnepf, E. (1996). Cryothecomonas aestivalis sp. nov., a colourless nanoflagellate feeding on the marine centric diatom Guinardia delicatula (Cleve) Hasle. Helgol Meeresunters 50, 497-515.

Ekelund, F. \& Patterson, D. J. (1997). Some heterotrophic flagellates from a cultivated garden soil in Australia. Arch Protistenkd 148, 461478.

Fenchel, T. (1987). Ecology of Protozoa: the Biology of Free-Living Phagotrophic Protists. Berlin: Springer-Verlag.

Godfray, H. C. J. (2002). Challenges for taxonomy. Nature 417, 17-19.
Guindon, S. \& Gascuel, O. (2003). PhyML - A simple, fast, and accurate algorithm to estimate large phylogenies by maximum likelihood. Syst Biol 52, 696-704.

Hargraves, P. E. (2002). The ebridian flagellates Ebria and Hermesinum. Plankton Biol Ecol 49, 9-16.

Hebert, P. D. N., Ratnasingham, S. \& deWaard, J. R. (2003a). Barcoding animal life: cytochrome $c$ oxidase subunit 1 divergences among closely related species. Proc Biol Sci 270 (Suppl. 1), S96-S99.

Hebert, P. D. N., Cywinska, A., Ball, S. L. \& deWaard, J. R. (2003b). Biological identifications through DNA barcodes. Proc Biol Sci 270, 313-322.

Hondeveld, B. J. M., Bak, R. P. M. \& van Duyl, F. C. (1992). Bacterivory by heterotrophic nanoflagellates in marine sediments measured by uptake of fluorescently labeled bacteria. Mar Ecol Prog Ser 89, 63-71.

Hoppenrath, M. \& Leander, B. S. (2006a). Dinoflagellate, euglenid or cercomonad? The ultrastructure and molecular phylogenetic position of Protaspis grandis n. sp. J Eukaryot Microbiol 53, 327-342.

Hoppenrath, M. \& Leander, B. S. (2006b). Ebriid phylogeny and the expansion of the Cercozoa. Protist 157, 279-290.

Huelsenbeck, J. P. \& Ronquist, F. (2001). MRBAYES: Bayesian inference of phylogenetic trees. Bioinformatics 17, 754-755.

Kimura, M. (1980). A simple method of estimating evolutionary rates of base substitutions through comparative studies of nucleotide sequences. J Mol Evol 16, 111-120.

Kühn, S. F., Lange, M. \& Medlin, L. K. (2000). Phylogenetic position of Cryothecomonas inferred from nuclear-encoded small subunit ribosomal RNA. Protist 151, 337-345.

Larsen, J. \& Patterson, D. J. (1990). Some flagellates (Protista) from tropical marine sediments. J Nat Hist 24, 801-937.

Lee, W. J. (2008). Free-living heterotrophic euglenids from marine sediments of the Gippsland Basin, southeastern Australia. Mar Biol Res 4, 333-349.

Lee, W. J. \& Patterson, D. J. (2000). Heterotrophic flagellates (Protista) from marine sediments of Botany Bay, Australia. J Nat Hist 34, 483-562.

Lee, W. J., Brandt, S. M., Vørs, N. \& Patterson, D. J. (2003). Darwin's heterotrophic flagellates. Ophelia 57, 63-98.

Lee, W. J., Simpson, A. G. B. \& Patterson, D. J. (2005). Free-living heterotrophic flagellates from freshwater sites in Tasmania (Australia), a field survey. Acta Protozool 44, 321-350.

Long, E. O. \& David, I. B. (1980). Repeated genes in eukaryotes. Annu Rev Biochem 49, 727-764.

Lynn, D. H. \& Strüder-Kypke, M. C. (2006). Species of Tetrahymena identical by small subunit rRNA gene sequences are discriminated by mitochondrial cytochrome $c$ oxidase I gene sequences. $J$ Eukaryot Microbiol 53, 385-387.

Marande, W. \& Burger, G. (2007). Mitochondrial DNA as a genomic jigsaw puzzle. Science 318, 415.

Massana, R. \& Pedrós-Alió, C. (2008). Unveiling new microbial eukaryotes in the surface ocean. Curr Opin Microbiol 11, 213-218.

Minelli, A. (1993). Biological Systematics: The State of the Art. London: Chapman \& Hall.

Myl'nikov, A. P. \& Karpov, S. A. (2004). Review of diversity and taxonomy of cercomonads. Protistology 3, 201-217.

Norman, J. E. \& Gray, M. W. (1997). The cytochrome oxidase subunit 1 gene (cox1) from the dinoflagellate, Crypthecodinium cohnii. FEBS Lett 413, 333-338.

Park, S. J., Park, B. J., Pham, V. H., Yoon, D. N., Kim, S. K. \& Rhee, S. K. (2008). Microeukaryotic diversity in marine environments, an analysis of surface layer sediments from the East Sea. J Microbiol 46, 244-249. 
Ronquist, F. \& Huelsenbeck, J. P. (2003). MRBAYES 3: Bayesian phylogenetic inference under mixed models. Bioinformatics 19, 15721574.

Saunders, G. W. (2005). Applying DNA barcoding to red macroalgae: a preliminary appraisal holds promise for future applications. Philos Trans R Soc Lond B Biol Sci 360, 1879-1888.

Schnepf, E. \& Kühn, S. F. (2000). Food uptake and fine structure of Cryothecomonas longipes sp. nov., a marine nanoflagellate incertae sedis feeding phagotrophically on large diatoms. Helgol Mar Res 54, $18-32$.

Scicluna, S. M., Tawari, B. \& Clark, C. G. (2006). DNA barcoding of Blastocystis. Protist 157, 77-85.

Skuja, H. (1939). Beitrag zur Algenflora Lettlands II. Acta Horti Bot Univ Latviensis 11/12, 41-169.

Šlapeta, J., Moreira, D. \& López-Garcia, P. (2005). The extent of protist diversity: insights from molecular ecology of freshwater eukaryotes. Proc Biol Sci 272, 2073-2081.

Sogin, M. L., Swanton, M. T., Gunderson, J. H. \& Elwood, H. J. (1986). Sequence of the small subunit ribosomal RNA gene from the hypotrichous ciliate Euplotes aediculatus. J Protozool 33, 26-29.

Stoeck, T. \& Epstein, S. (2003). Novel eukaryotic lineages inferred from small-subunit rRNA analyses of oxygen-depleted marine environments. Appl Environ Microbiol 69, 2657-2663.
Tamura, K., Dudley, J., Nei, M. \& Kumar, S. (2007). MEGA4: molecular evolutionary genetics analysis (MEGA) software version 4.0. Mol Biol Evol 24, 1596-1599.

Tautz, D., Arctander, P., Minelli, A., Thomas, R. H. \& Vogler, A. P. (2002). DNA points the way ahead in taxonomy. Nature 418, 479.

Tautz, D., Arctander, P., Minelli, A., Thomas, R. H. \& Vogler, A. P. (2003). A plea for DNA taxonomy. Trends Ecol Evol 18, 70-74.

Thompson, J. D., Higgins, D. G. \& Gibson, T. J. (1994). Clustal W: improving the sensitivity of progressive multiple sequence alignment through sequence weighting, position-specific gap penalties and weight matrix choice. Nucleic Acids Res 22, 4673-4680.

Thomsen, H. A., Buck, K. R., Bolt, P. A. \& Garrison, D. L. (1991). Fine structure and biology of Cryothecomonas gen. nov. (Protista incertae sedis) from the ice biota. Can J Zool 69, 1048-1070.

Uhlig, G. (1964). Eine einfache methode zur extraktion der vagilen, mesopsammalen Mikrofauna. Helgol Wiss Meeresunters 11, 178185.

Vørs, N. (1993). Heterotrophic amoebae, flagellates and heliozoa, from Arctic marine waters (North West Territories, Canada and West Greenland). Polar Biol 13, 113-126.

Weisse, T. (2008). Distribution and diversity of aquatic protists: an evolutionary and ecological perspective. Biodivers Conserv 17, 243259. 